\title{
Composite Vernacular Constructions
}

\author{
Miles Lewis \\ University of Melbourne, Melbourne, Australia \\ Email: miles@mblewis.net
}

\begin{abstract}
Vernacular building is the building for ordinary people, constrained by the practicalities of environmental conditions and physical materials, and influenced by traditional culture, but not mediated by professional architects and engineers. Combinations of earth and timber, such as wattle and daub, are found in the vernacular in almost every part of the world, but are a source of great confusion to archaeologists and scholars. Archaeologists are misled by the remains, in which the earth may have survived but the timber usually does not. Techniques such as Lehmwickel are never recognised in archaeological work. There is no common system of naming or classification, and English speakers regularly describe any combination of earth and timber in walling as 'wattle and daub'. Many of these techniques have been changed by the impact of modern technology, notably pole and pug construction (which is often confused with wattle and daub, though it is quite different in principle); this is essentially a $19^{\text {th }}$ century development because it relies upon plentiful and cheap nails. The purpose of this paper is to establish a common terminology in English, and where possible in other relevant languages, so that misinterpretations are avoided and scholarship can proceed on an orderly basis.
\end{abstract}

KEYWORDS mixed construction, wattle and daub, lath and pug, Lehmwickel, pole and pug, nails

Received October 4, 2019; accepted December 23, 2019.

\section{Introduction}

Descriptions of vernacular structures are often tantalisingly vague or inaccurate. It is impossible to say whether a technique has originated in one part of the world and then been transmitted to another when the terminology used in the two places is different and the standing structures are, often enough, impervious to analysis. For in most of the techniques considered here (and in all of those used with half timbering) it is normal to plaster or daub the surface, so that the structural components are invisible.

Detailed written accounts tend to be European, and especially English. An attempt is made here to establish a taxonomy of composite vernacular construction based largely upon European sources, and then to extend it to other parts of the world where the information is available. It will be described in English, and where appropriate French, German, or Spanish. Even with these limitations it should enable scholars in other languages to find common ground.

An example of archaeological vagueness is the frequent reference to pisé de terre in the eastern Mediterranean and Mesopotamia. This is completely unwarranted, for the technique was developed by the Phoenicians in North Africa and Sicily, and is unknown further to the east. In relation to Cyprus, the archaeologist Gordon Thomas (as I am advised by Professor Bernard Knapp) cautioned against the misuse of the term, but was ignored. Rammed earth, which is the same thing, was developed independently in China, but there seems to be no evidence to support the common assertion that the walls of Pingyao are of this construction. On the contrary all the indications are that they are the same as the many walls to be found in the surrounding area today-a mud formed of the local loess soil, and faced on either side with adobe and/or baked brick. This form of mud construction is also distinct from cob, which contains an admixture of straw, and so far it has been reported only in China. I have attempted elsewhere to give some sort of historical and taxonomic structure to our understanding of earth building in its heartland-the Middle East and Mediterranean (Lewis 2017).

In forms of construction which combine earth and timber there is even more potential for confusion. A reference to structures of wood poles, cane and mud at Supe, 
Figure 1 Earthfast construction compared with the box frame, which is independent of the ground and requires some form of bracing (Source: Terence Nott).
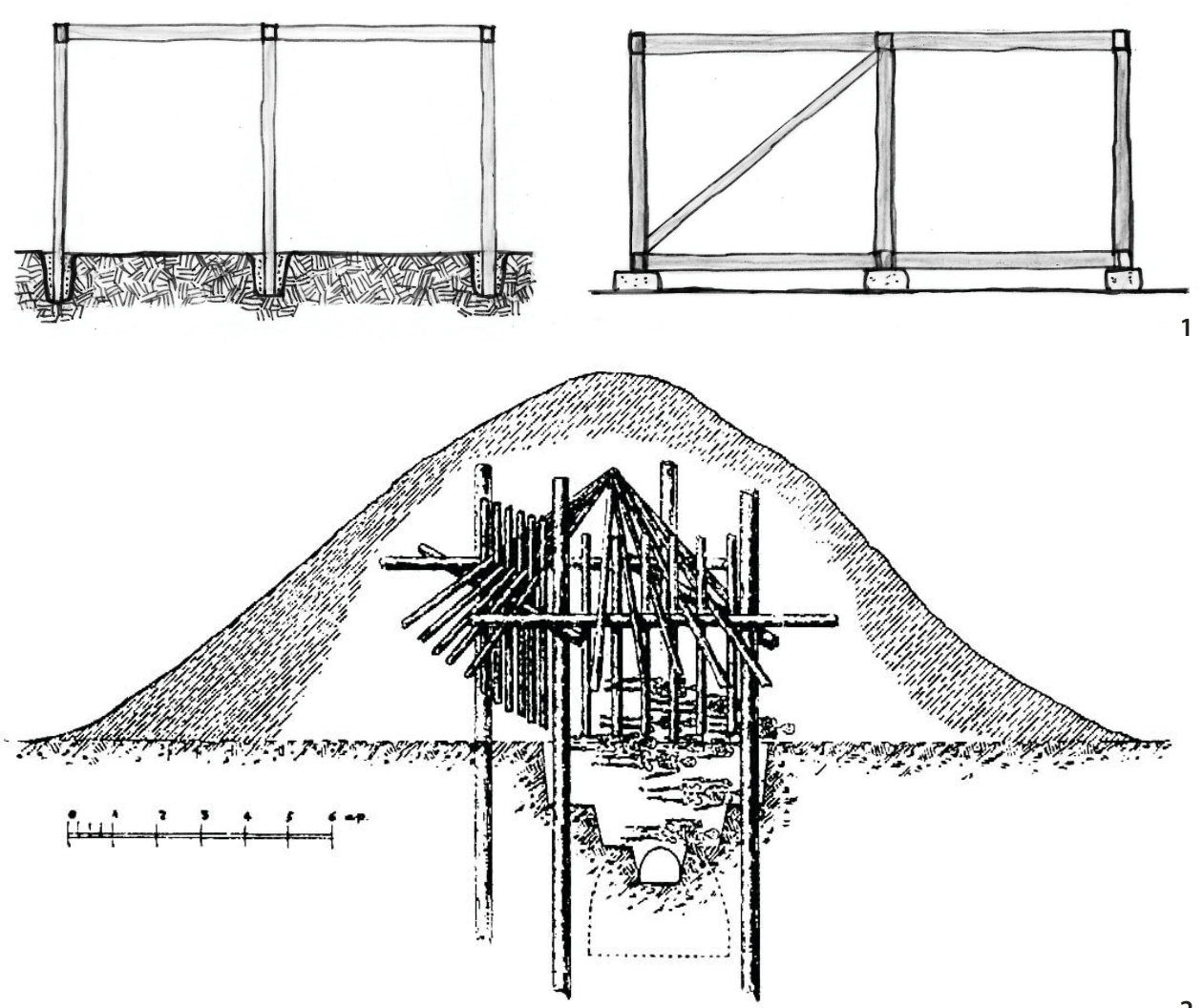

Figure 2 Barrow I, Kostromskaya, early $6^{\text {th }}$ century $B C$, isometric diagram (Source: Artomonov 1969, drawing V).

\section{Earthfast Construction}

For obvious reasons most primitive structures of earth and timber have vanished. Earthfast construction, with the posts set directly in the ground, is an early and primitive way of building (Figure 1). The components do not have to be cut accurately, and they gain their stability from the ground, rather than requiring complicated framing and jointing techniques. Except in acid environments such as peat bogs they do not survive well, for apart from the usual threat of fire, they are exposed to moisture in the ground and consequent decay. But earthfast posts may nevertheless leave traces, because if they are burnt the ash, the charcoal, or even actual charred timber remains. The same is true of palisade construction (rows of slabs or poles set in the ground).

An example is a Scythian tomb of the $6^{\text {th }}$ century BC (Artamonov 1969, 31) (Figure 2). The Scythians were essentially nomadic people from central Asia who occupied the area between the Black Sea and the Aral Sea from the $8^{\text {th }}$ to the $4^{\text {th }}$ century BC, and the tomb is important evidence of their lifestyle, for it probably imitates an above-ground dwelling type, with earthfast posts and a hipped conical roof. Although the structure was burnt, charred remains of the posts survived. Late Bronze Age houses at Pryssgården, Sweden, presented a 

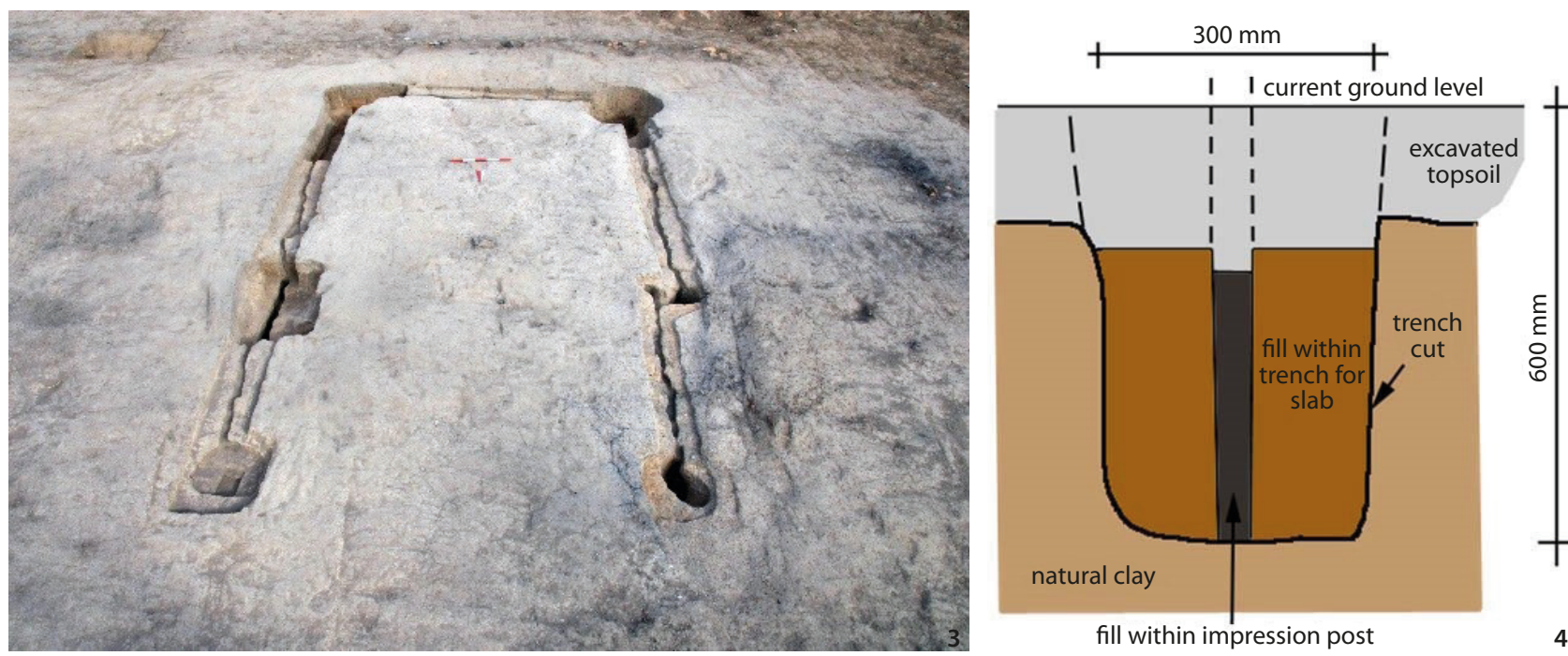

Figure 3 Gavin house site, Penrith, Australia, evidence of posts and palisade walling (Source: Archaeology and Heritage P/L).

Figure 4 Gavin house site, Penrith, Australia, evidence of palisade wall (Source: Franz Reidel, AAH. Archaeology and Heritage P/L.)

more difficult problem. The post holes were visible but the walls were not of earthfast construction, so that their locations were largely a matter of guesswork (Bradley 2005, 54).

Although earthfast posts and palisades are sometimes pointed to help set them in place, they are not driven into the ground like piles, but are placed in an excavated hole or trench, as the case may be (Figure 3, Figure 4). Therefore the disturbed soil used in backfilling may also be observable by an alert archaeologist.

\section{Half Timbering}

The alternative to earthfast construction is to use a ground plate or floor plate as the base of a framed structure, which may then be raised off the ground on a masonry plinth, padstones or timber stumps. Such a structure is more durable, but may be removed to leave little or no trace. Because it gains no strength from the ground it must be fully braced, and this bracing is commonly expressed visually. It is known in English as 'half timbering', which is approximately equivalent to the German Fachwerkbau and the columbage of Normandy. The panels of such a frame might be filled according to any one of the techniques discussed below.

An interesting case is California, which had a Spanish tradition of building in adobe. Framing was a revolutionary idea, introduced by the United States consul, Thomas Larkin, in the house which he built, using redwood, in 1834-5. Larkin's house is the first example of what became known as the Monterey Style, in which framing and adobe were combined. (Smith 1981, 126-127)

\section{Framed Pug}

The simplest means of filling a frame was with mud, or pug, though it adds little strength to the structure, and therefore does not strictly qualify as mixed construction. An English system which seems to have been fairly widespread early in the $19^{\text {th }}$ century consisted of daub on straw:

... a few uprights and braces, with a plate of fir at top and bottom, will be sufficient, and the vacancies filled in with thatching stuff placed close together, having three or four pieces at equal distances, nailed horizontally to keep them firm, will be ready to receive the clay, with which a good quantity of cut straw should be incorporated, to make it adhere better (Lugar 1807, 2).

The 'cab-dab' of the west of England was essentially similar, except that the studs were round timber spaced vertically about $150-175 \mathrm{~mm}$, then filled with mud and straw (Crocker 1804, 174). Similarly, the first 'Government House' at Adelaide, Australia, was described as 'constructed of mud, put between laths, supported by uprights of native wood' (Gouger 1838, 68). In Canterbury, New Zealand, Charlotte Godley referred to 'cob' houses consisting of a 'frame of poles filled with clay' (Godley 1951, 159).

\section{Wattling}

Wattling is a basketwork of woven twigs or laths used in many cultures for roads, paths and fences, and especially for the walls of structures such a grain stores, which require ventilation at the same time as protection from 


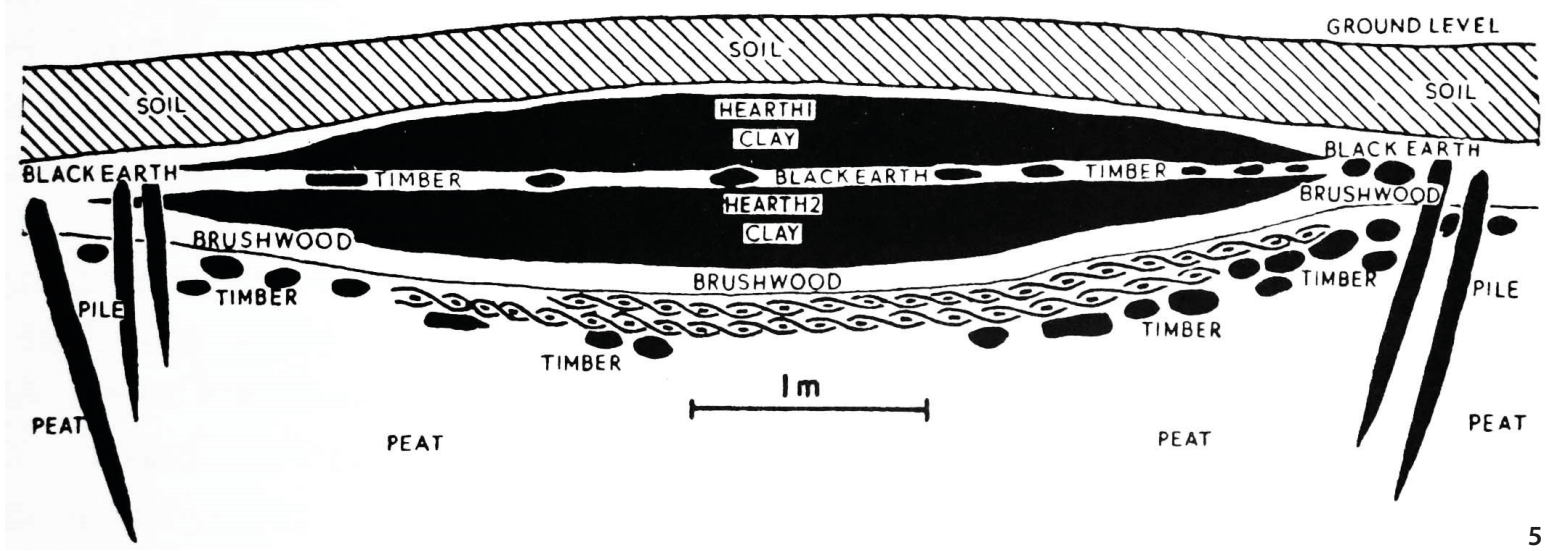

Figure 5 Section through a mound (LVI) at Glastonbury Lake Village, England, showing the layer of wattle hurdles of a trackway towards the bottom (Source: Bradford 1954, 319, after A. Bulleid and H. St. G. Gray. 1911. The Glastonbury Lake Village. Glastonbury: Glastonbury Antiquarian Society, vol. 1, p. 134, figure 1).
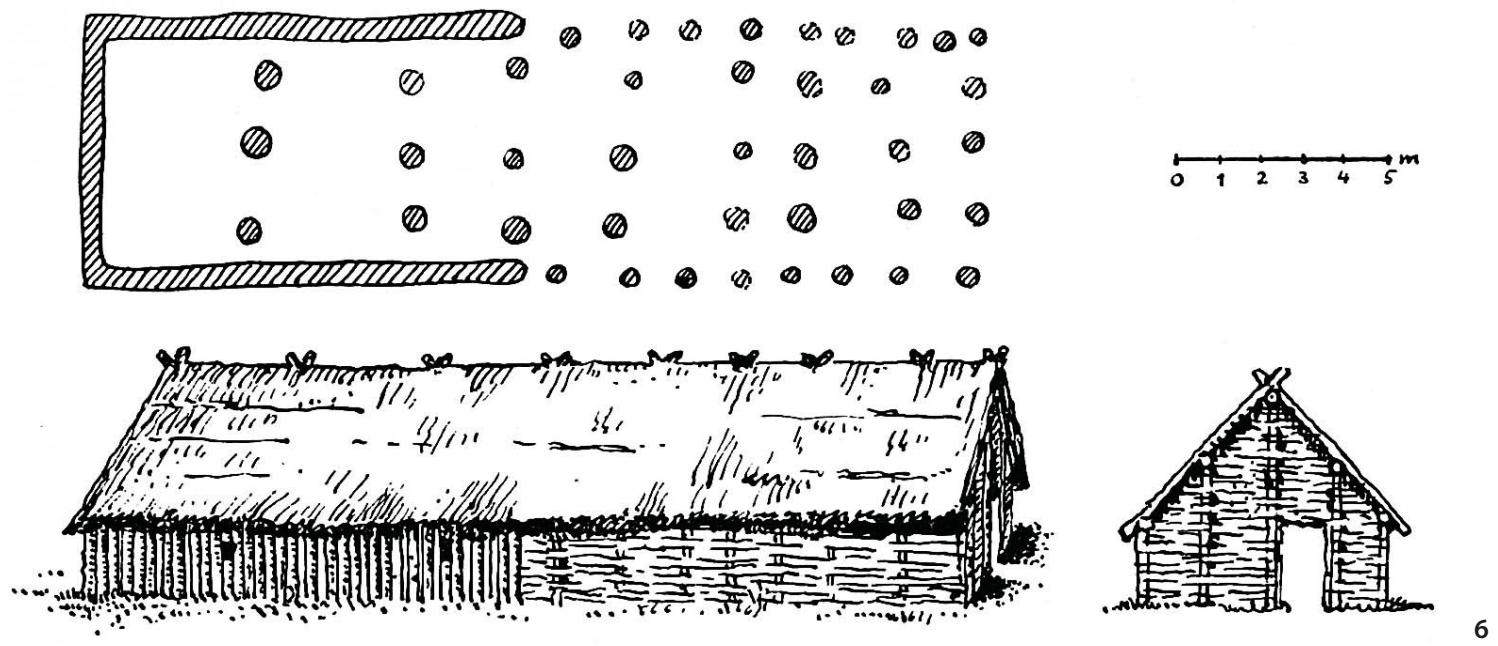

Figure 6 Ground plan and reconstruction of a typical long house at Köln-Lindenthal. Germany, c 4500-4300 BC; palisaded at the left and wattled at the right (Source: Paret 1942, 91).

vermin (Figure 5). It can be set within a timber frame by boring or mortising holes in the horizontal members to receive the vertical laths or larger members, while the twigs, or horizontals are sprung into grooves in the sides of the timber verticals of the frame. In more modern times, with nails more readily available, the horizontals may be nailed to either side of an attached cleat, rather than sprung into a groove.

One of the earliest known European examples appears to be the Abbot's Way in Somerset, England, an early neolithic trackway of about $2500 \mathrm{BC}$, made of round timbers and planks of alder and other woods, apparently wattled together, and laid over marshland to create a sound surface (Coles 1983). At Glastonbury Lake Village, c. 250-50 BC the houses were built on peaty mounds or islands on which materials were laid, and surrounded by a palisade: while wattling was used in the lower layers. Wattling was later used in England by the Romans, for example at Housesteads fort.
In a Danubian long house at Köln-Lindenthal one end is palisaded, and would probably have been chinked with moss and mud to make it weatherproof, while the other end was wattled and probably accommodated livestock and produce (Figure 6).

Wattling was used all over the world where permeable walls were required, but even more common were walls of wattling plastered over to seal it, which is described as wattle and daub (Figure 7).

\section{Wattle and Daub}

Wattle and daub is the best-known hybrid technique, used in most cultures across the world, but the term is commonly misused (Figure 8). It applies only to wattlingwhich is a basketwork of woven twigs-which has been daubed or plastered with some form of mud or lime composition. Wattle and daub is said to have been used as a 

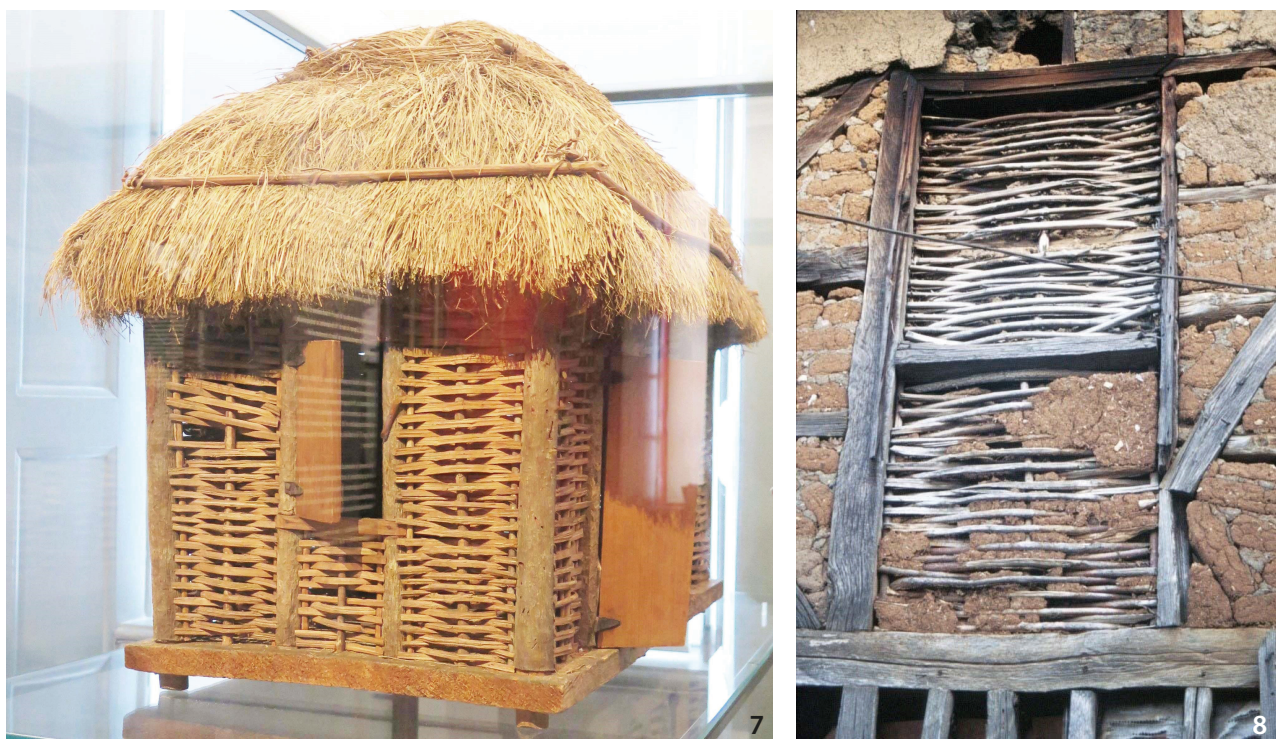

Figure 7 Model of a Danish slave house in the West Indies, Nationalmuseet, Copenhagen (Source: the author).

Figure 8 Wattle and daub at Cumalikizak, Turkey (Source: the author).

building material at Middle Stone Age sites as far apart as Belgium and Palestine. But its origins are obscured by the lack of clarity in archaeological reports. A structure at Tell es-Sultan, Jordan, of about 9000 BC, was said to be 'built on a platform (and) consisted of posts and mud, indicating wattle-and-daub construction' (Van Beek 2007, 7). But that inference is completely unwarranted, for there are many alternative interpretations.

We are on safer ground in Europe, though even there it is likely that the remains of other forms of construction, such as Lehmwickel (totally unknown to archaeologists) have been misinterpreted as wattle and daub. The remains of some of the earliest British wattle and daub buildings have been found in Somerset, at Glastonbury Lake Village (Bradford 1954, 320). and nearby at Meare, from of about 200 BC (West 1971, 14). Wattle and daub was also a form of construction known to the Romans (Pliny 79, book $\mathrm{xxxv}$, chapter xlviii) and is commonly assumed to have been the infill in opus craticum, Roman half-timbered construction. Since Roman times it has been indigenous to many parts of Britain: as the stud and mud of Leicestershire; the clam, staff and daub of Lancashire; the freeth or vreath of the West; the rad and dab or raddle and daub of Cheshire; and the rice and stower of the North (Innocent 1916, 126-134; Cook 1954, 14; Papworth 1853-1892, svv; Wattle and Dab, Rad and Dab, Tapia, \&c). The typical English method consisted of vertical rods of hazel sprung into prepared grooves in the framing, between which thinner rods were woven in and out horizontally to form a basketwork, and both sides of the basketwork daubed with a mixture of clay, water and straw, sometimes with cow dung. In East Anglia the vertical hazel sticks, known as 'rizzes' or 'razors', were left with their bark on and no horizontals were used (Cook 1954, 14). Variants include 'stake and rice' in which reportedly slabs or poles are interwoven with ropes or brush bush.

In Ireland 'sally rods', osiers, twigs, switches, hay or straw ropes, or briars were interwoven between stronger timbers, either vertically or horizontally (Danachair 1957, 74). In Spain, where the technique is known as encestado (referring to the woven basketwork, but not to the daub), it was used in Castilian and Basque buildings, especially in the valleys of rivers such as the Douro. In the north, internal partitions are commonly of this construction, as are the spectacular chimneys, pinariegas, of Burgos and Soria. The daub is mud, with a lime surface, and the weaving can be in a zig-zag pattern, known as a 'lamprey', or of other forms such as 'flat mat' or 'pine shoot mesh' (Arellano 2006, 14-15).

In France an $18^{\text {th }}$ century description of how to build a beehive reads:

To make the side and front wall you drive pieces of wood into the ground about one-and-a-half feet apart, making them the same height as the main posts of the structure: to fix them better and more soundly you put two or three crossways, and nail these to the posts: you interlace into these timbers branches of willow or any other wood, and apply to the outer face a coating of clayey soil beaten up with water to make a sort of mortar; failing clay earth you can use ordinary earth mixed with a little chalk to make it bind better. (Rozier 1793-1800, vol. 1,56$)^{1}$

It is not surprising that the technique migrated to 

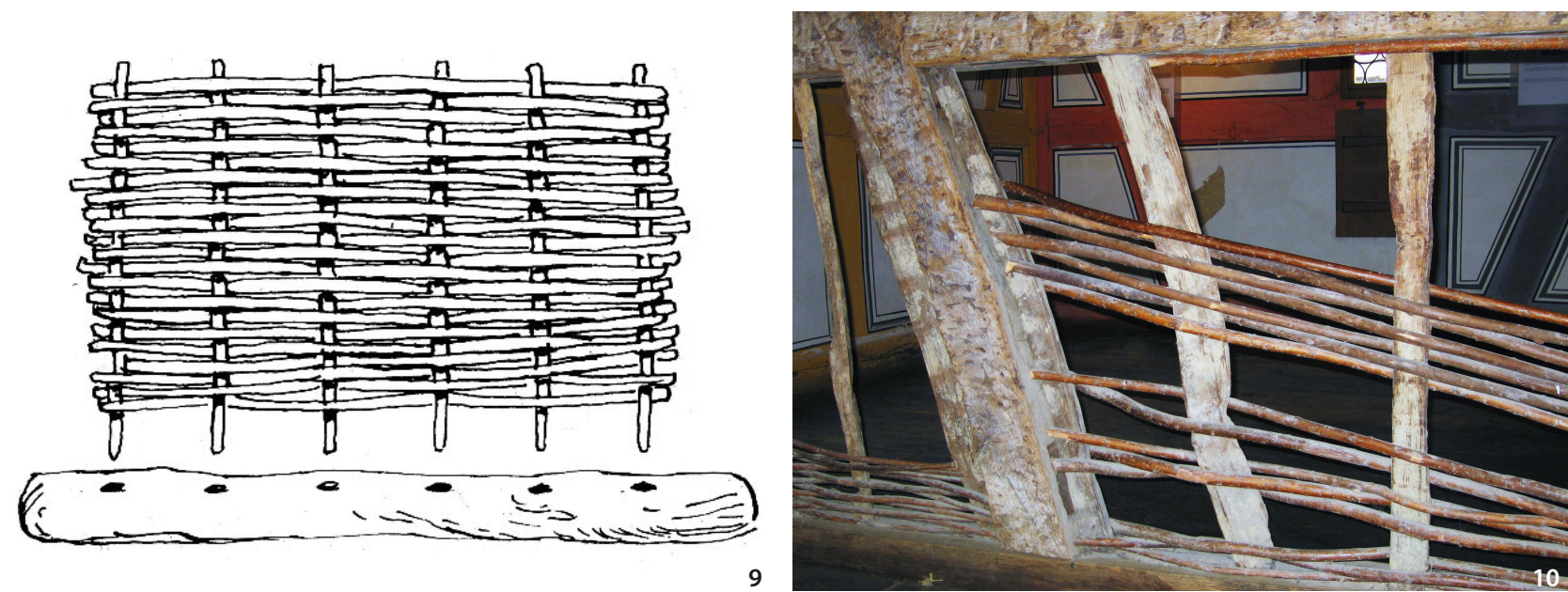

Figure 9 Wattling for wattle and daub in China (Source: Edwards 1984, 73).

Figure 10 Hohenlohe Freilandmuseum, Germany. Wine grower's house from Sachsenflur, 1562, remains of a wattle and daub attic partition wall (Source: Miles Lewis).

French colonies, but what is surprising is that the term used in Québec, gasparde (Arthur and Witney 1998, 117), does not seem to be used in France itself. Wattle and daub is also known in China, Mexico, and elsewhere (Figure 9).

\section{Lehmwickel}

Lehmwickel is a more specialised type of German origin, and widespread in German settled areas from Brazil to Australia. It consists of a pole, stake, or flat slat of wood with pointed ends, around which is rolled a layer of straw in a clay or mud slurry. When this was dry, or probably nearly dry but still a little soft, it was set in a ceiling with the pointed ends resting in grooves in the sides of the joists, or on top of strips planted onto the sides. A row of these units set close together was a good insulator of sound between floors or of heat below a roof. Otherwise they might be placed vertically in the panels of a Fachwerkbau or half-timbered wall and plastered over on at least the external face. In a related technique, Lehmspundwand, straw and mud were applied to the stakes only after they were placed in position

The age of Lehmwickel is difficult to judge. Some of the earliest surviving examples of Lemwickel ceilings in masonry buildings date from the $16^{\text {th }}$ century, but timber framed examples are likely to have been far more common and far earlier, even if they have not survived in recognisable form. Even the archaeological record is unhelpful, because-as discussed above-early timber-framed ground sills with holes in them are generally assumed to indicate wattle and daub. A day labourer's cottage from Oberwittstadt Neckar-Odenwald-Kreis, dated 1564, and now in the Odenwälder Freilandmuseum Waldürn-Gottersdorf, is said to contain original fabric and it appears (from a drawing) to contain Lehmwickel. But this could well have been installed later, perhaps after a fire which occurred in 1777 (Bedal 1999, 87). A wine grower's house from Sachsenflur, Germany, 1562, now in the Hohenlohe Freilandmuseum, contains Lehmwickel, but, however accurate it may be, it presumably dates from the moving and reconstruction of the building (Figure 10).

This is a case where the lack of archaeological understanding is a serious problem, for the evidence seems to suggest that the technique was associated with the Germanic tribes which irrupted into the declining Roman empire-that is, not only the Germani but also the Franks. This would explain the presence of the technique in Brittany and Normandy-and not in the south of France which, though conquered by the Franks remained highly Romanised (Figure 11).

In Brittany, according to Meirion-Jones, Lehmwickel (to continue with the German term) was surfaced with a layer of clay when used in upper floors of peasant houses, or with tile flooring in seigneurial residences. He refers to houses at Coadélan (Prat, Côtes-d'Amor), of the $13^{\text {th }}$ century but burnt out and renewed in recent times, and La Salle (Plurien, Côtes-d'Amor) possibly $14^{\text {th }}$ century, as well as the Château of Le Bois Orcan (Noyal-sur-Vilaine, Ille-et-Vilaine, about $1 \mathrm{~km}$ north of Châteaugiron, near Rennes) where there are floors of this sort dating from before 1515 (personal communication with Meirion-Jones on 12 February and 10 March, 1996). Elsewhere he refers to a loft flooring system called doubli or doublyi which consists of 'atons of wood and clay' known as grenouilles or baguettes in the Loire-Atlantique dialect. But the word 


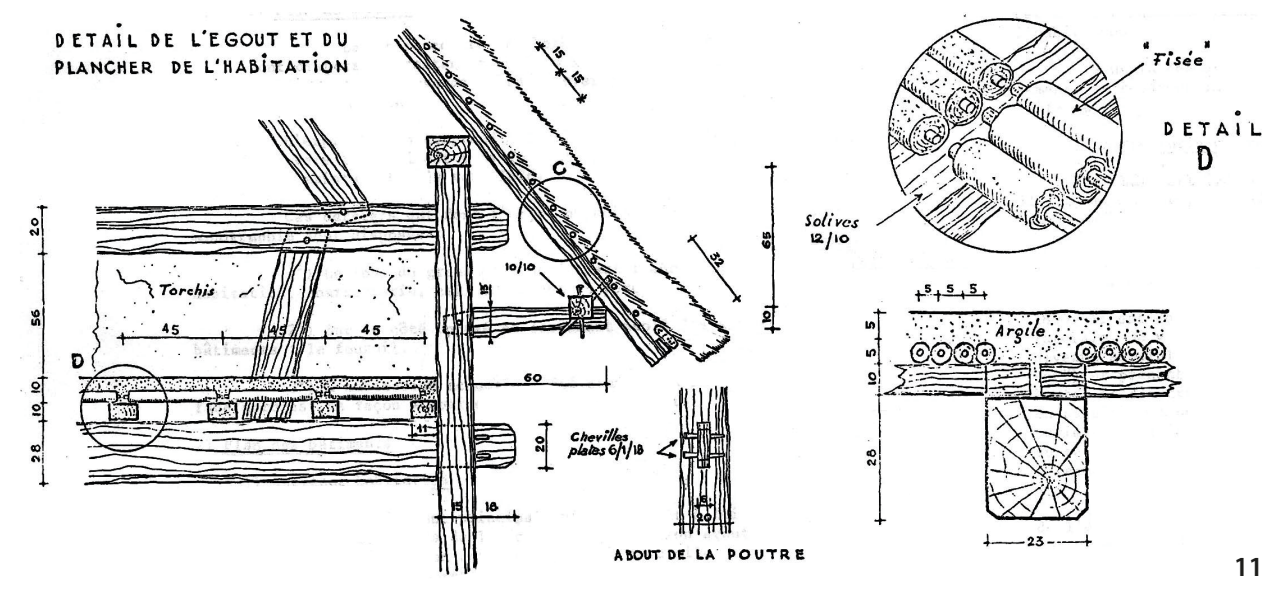

Figure 11 Farmstead of La Turbie, St Saire, Normandy, details of fisées in the ceiling (Source: Rivière 1940s, 104 [reformatted]).
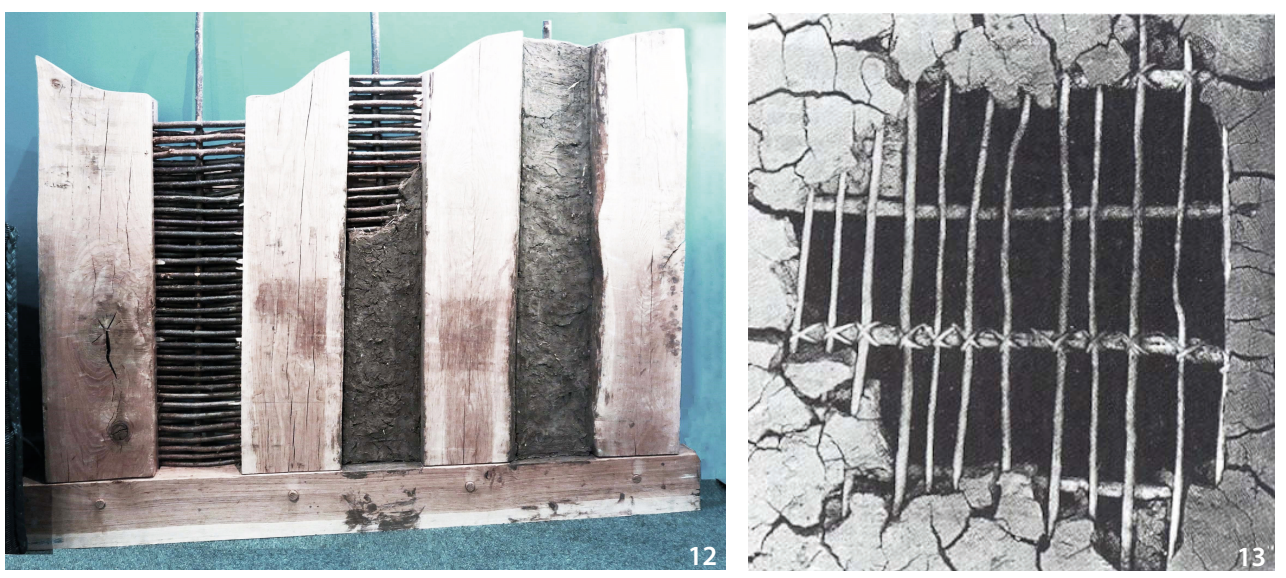

Figure 12 Eynsham Abbey, Oxfordshire, UK, reconstruction of part of an Anglo-Saxon wall, probably before the $10^{\text {th }}$ century, based upon the imprints left in the plaster, Woodstock Museum, Oxfordshire (Source: Miles Lewis).

Figure 13 Sapling and daub wall, Chenalho, Chiapas, Mexico (Source: Rogello Cuéllar, Prieto 1994, 32).

generally used in the region today is quenouilles. A baton of 550 to $650 \mathrm{~mm}$ has a mixture of clay and hay wound around it, to a finished diameter of 80 to $100 \mathrm{~mm}$. Before they have fully hardened, these baguettes are laid between beams, touching each other, and when they are dry a layer of torchis or pisé (in fact two very different things, and torchis must be intended) is applied to create a smooth floor (Meirion-Jones 1982, 61).

\section{Grid and Daub}

A number of methods using canes, bamboos or timber rods resemble wattle and daub, but are not in fact wattled. And this distinction is itself often unclear. The bajareque of the Dominican Republic as reported is a form of wattle and daub (Vicioso 2019, 94) whereas the bahareque of Cuba is simply a grid of rods, daubed over (Melero 2016, 224).

The simplest of these methods is a medieval one in which the studs are so close together that small horizontal rods can span directly between them, as was the case at Eynsham Abbey, Oxfordshire (Figure 12). In Normandy there is a version called andouillage in which only slender vertical members are used, set within the panels formed by the main posts of the structure.

If the spacing is larger there needs to be some sort or grid or mesh, combining vertical and horizontal members. As these are not woven they need to be fixed together in some way to develop any strength. In Mexico, Japan, and elsewhere, round rods or canes are tied at some or all of the intersections (Figure 13, Figure 14). In Japan the daub is commonly reinforced with rice straw. G-H Rivière illustrates an example at Grecey (Manches), France, in which the main posts are about $130 \mathrm{~mm}$ square. The intermediate verticals are flat slats about 80 $\mathrm{mm}$ wide, spaced at about $280 \mathrm{~mm}$ and clad on either side with quite irregular saplings, or in fact little more than twigs-close to the components of wattle and daub in proportion, but with no interweaving. This creates an armature or lattice which is filled with earth and plastered on each face to finish flush with the main posts, about $180 \mathrm{~mm}$ thick in total (Rivière 1940s, 20). The Fairbanks house at Dedham, USA, of 1637-1641, had horizontal timber bars sprung into grooves in the studs, supporting vertical sticks of split oak, which were filled around with whitish clay (Morrison 1952, 43). 

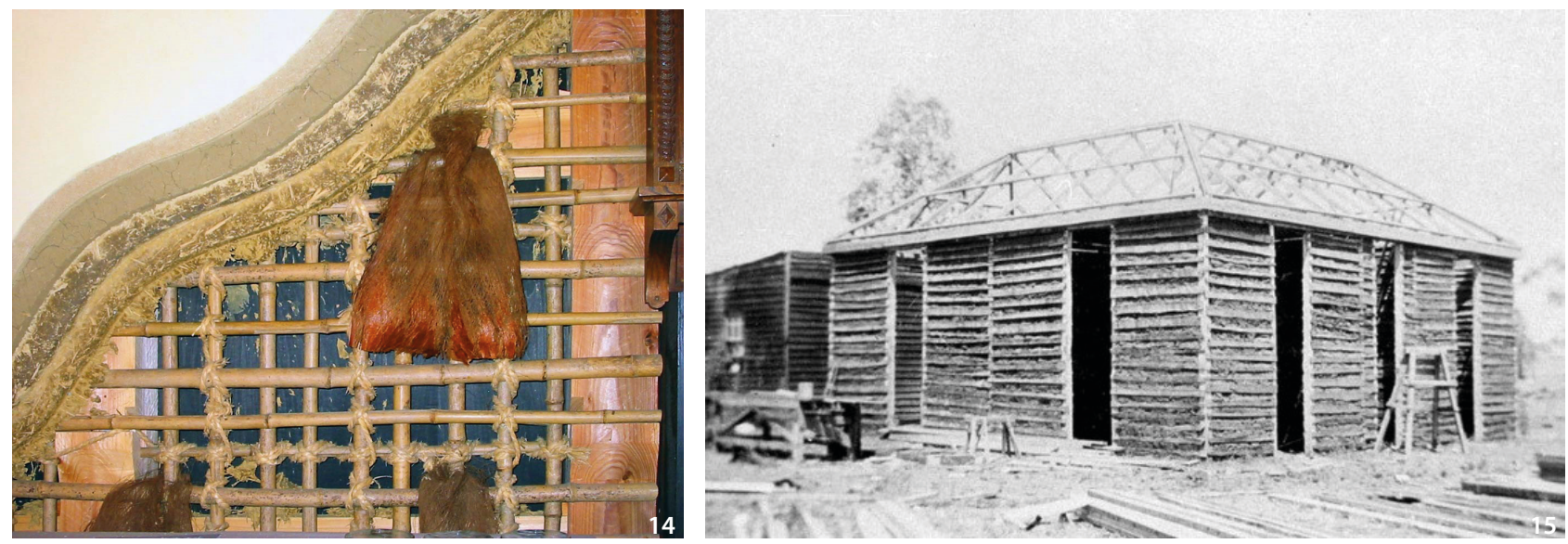

Figure 14 Cane and daub wall, Uchiko, Japan, interpretative display showing the layers of mud plastering (Source: Miles Lewis).

Figure 15 'Rocky View', Alectown, New South Wales, under construction, 1914 (Source: State Library of New South Wales, Sydney, 00058).

\section{Lath and Pug}

It is convenient to use the term 'lath and daub' for construction in which split laths (rather than poles) are nailed right across the face-or both faces-of the wall, and the cavity is filled with pug. I distinguish pug from daub in that the material, though similar, is a filling rather than a coating. Although lath construction is dependent upon the use of relatively expensive nails, it would have been familiar from internal plastering, and therefore may have been adopted sooner than pole and pug construction as discussed below.

This seems to be largely a British technique, and is the antecedent of pole and pug construction. In England in 1775 Nathaniel Kent advised that 'Where pollards are plenty, and bricks scarce, it will sometimes be proper to prefer the wooden-lath and rough-cast cottages.' (Kent $1775,243)$ In 1805 William Atkinson advocated the use of timber posts of about 4 inches $(100 \mathrm{~mm})$ diameter at 15 inch $(780 \mathrm{~mm})$ spacing, clad on both faces with plastering laths. The outside was to be plastered in clayey mud mixed with chopped straw, and the inside with mud or with lime and hemp (Atkinson 1805, 13-14). Loudon refers to this as 'rab and dab', a means of constructing internal partitions, implicitly in a building with external walls of cob: 'instead of brick-nogging for partitions cob is used for filling in the frame work which is previously lathed with stout slit oak or hazel branches in place of laths.' (Loudon 1846, 417).

According to McCann, 'mud and stud' buildings, which he equates with timber and laths, were built in many parts of England, but the majority of survivors are in Lincolnshire (McCann 2004, 13). He seems to be conflating two different things, the widespread tradition of horizontal lathing, which is particularly common in Essex, and the inappositely named 'mud and stud' using vertical rods or split pieces, known only in Lincolnshire (as discussed above). In the early $20^{\text {th }}$ century, according to Ketteridge and Mays, practice in Essex was to use split ash poles as laths, and a coating of clay reinforced with straw and chaff (Ketteridge and Mays 1972, 33).

In the United States, the Whipple house at Ipswich, Massachusetts, of 1677, had square posts carrying clapboard on the outside and horizontal split laths on the inside, the space between substantially filled with mud, and the inner surface finished smooth over the laths. (Morrison 1952, 43). In Wellington, New Zealand, Petre's house was built 'in imitation of Essex farm houses' of lath and plaster, coated in roughcast (Godley 1951, 74). Peter Cunningham, writing of New South Wales, Australia, refers to construction of split timber and plaster, as distinct from wattle and daub (Cunningham 1827, II, 161), and when Philip Oakden bought the King's Meadows farm outside Launceston in 1834 there was an 'old lath and plaster' house on the site (A. Bailey and R. Bailey 2004, 23) (Figure 15). But laths occur in only a small minority of $19^{\text {th }}$ century Australian examples, and where they are mentioned in written descriptions, it is more likely the result of inaccuracy. On the other hand, a number of examples of this technique are known in Australia dating from the early $20^{\text {th }}$ century

\section{Pole and Pug}

There was a major change in principle when instead of filling within the panels of a timber frame, first laths, and then poles or saplings, were nailed horizontally to both faces of the frame, and then filled with mud. It is more 

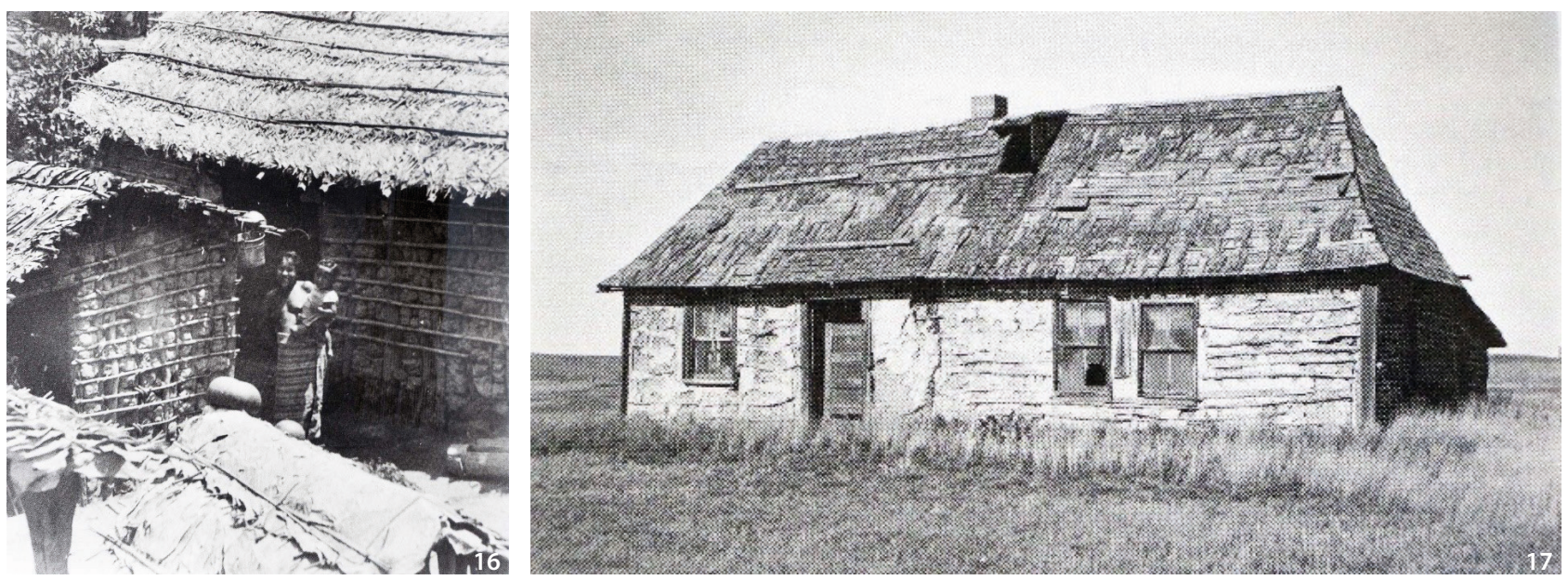

Figure 16 Jamiltepec, Oaxaca, Mexico (Source: Walter Reuter, Prieto 1994, 32).

Figure 17 Petro Demaniew house, Dakota, USA, 1908 (Source: Martin 1989, 89).

a question of packing the mud within the timbers, than of plastering or daubing it on the outside faces. This is a widespread form of construction, but seems to appear only in the $19^{\text {th }}$ century, and there can be little doubt that it was brought about by the availability for the first time of cheap nails, and probably the wire nail in particular. It is found in Ireland, in Australia, in Mexico and elsewhere in North America (Figure 16). In Australia it seems to evolve from mining works.

A method of this sort is reported in Ireland (in addition to true wattle and daub): light timbers are nailed to the face of the uprights at intervals of about $300 \mathrm{~mm}$, said to resemble the rungs of a ladder (Danachair 1957, 74).

In the United States such construction is found in two quite different contexts. One is that of Ukrainian settlers, who undoubtedly brought the technique from their homeland, and from Galicia in particular, but another seems to be a spontaneous local development. A Ukrainian settler of the early $20^{\text {th }}$ century recalled his family house in Boryskivtsi, 'built by digging poles into the ground. Between the poles we constructed a grillelike framework and filled it with earth'. Another said: 'Our homes were made with poles set up in the ground and fastened smaller poles to the upright posts and the cracks were filled or plastered with mud mixed with hay or straw. They were finished with mud alone so it would be smoother' Other examples of this construction have also been identified amongst Ukrainian buildings in Saskatchewan, Canada, though log construction is more common (Martin 1989, 89).

Construction of this sort also characterises a $930 \mathrm{~km}^{2}$ area of western North Dakota in which nearly forty such structures have been found (Martin 1989, 86) (Figure 17).
Christopher Martin describes the horizontal members as laths, but it is clear from an illustration that they are saplings in the round (though there are later variants using sawn lathing). The posts were of cedar, about $150 \mathrm{~mm}$ in diameter and 0.9 to $1.2 \mathrm{~m}$ apart, the horizontals were of willow, and the filling was a mixture of earth, dung and straw, locally known as 'gumbo'. Sometimes small rocks were placed in the bottom of the frame, to resist erosion.

In Boyd County, Nebraska, buildings by what are described as 'German-Russian-Americans' used much the same system, with willow uprights, willow poles, and a packing of mud and straw (Murphy 1989, 81). The same form of building is found amongst the Papago Indians, near the Mexican border. The buildings are flat-roofed and the posts, which are relatively lightweight and closely spaced, have been selected with natural forks to hold the roof beams. In some cases, the poles run horizontally, exactly in accordance with the method already discussed, but in others about four poles run horizontally, and the close-set poles are vertical (Nabokov and Easton 1989, 344-345).

It can by no means be inferred that this is an indigenous tradition, for the Indians in the region had been in contact with Europeans since 1540, and it is worth bearing in mind how much more difficult such a building technique would have been before nails were available. A very similar horizontal pole and pug technique has been found in the Great Basin area of Nevada, where the buildings are known as 'mud', 'pole' or 'Indian' houses, and certainly there is no Ukrainian component. However, Blanton Owen sees them as having been a spontaneous local development rather than something derived from the Indians (Owen 1989, 245-246). Whether or 


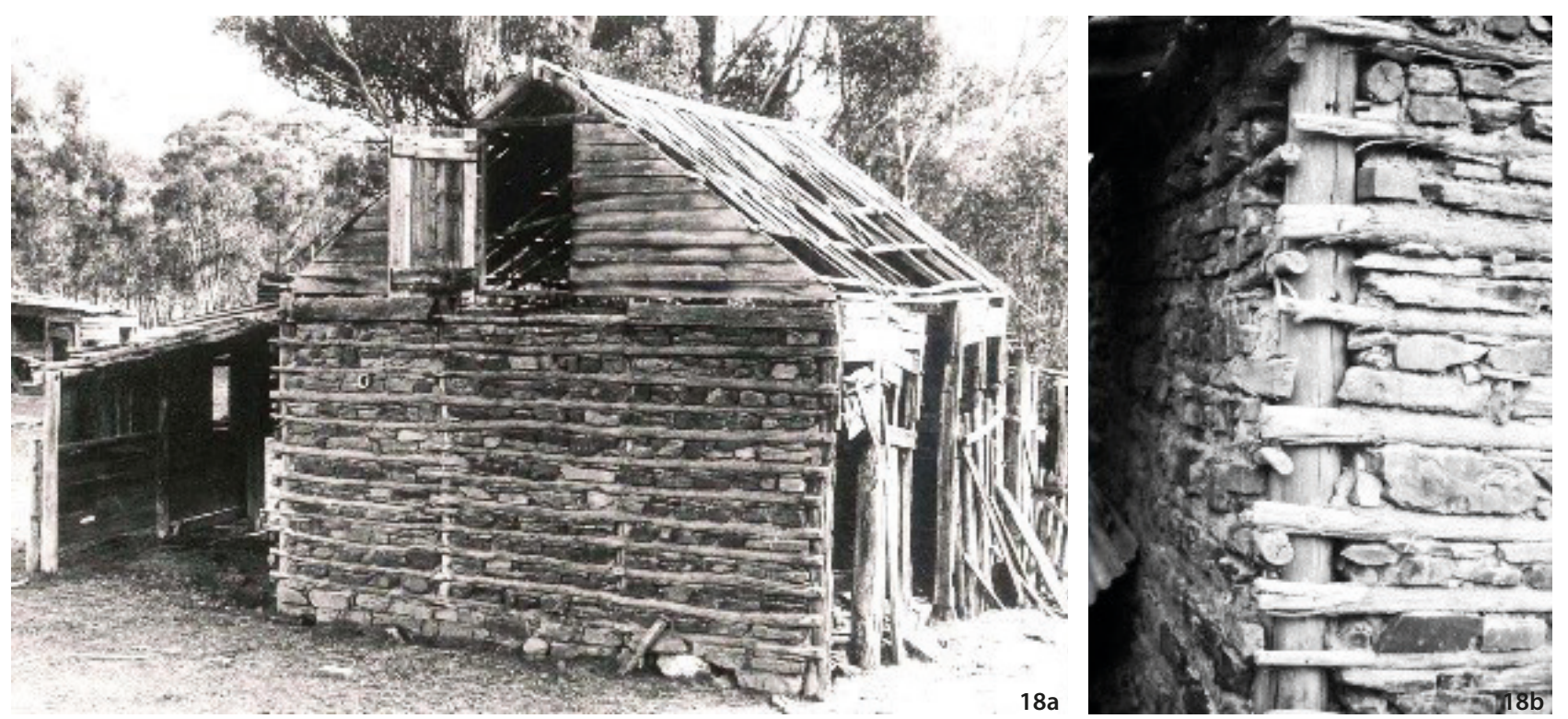

Figure 18 Duer's barn, Maldon, Australia, 1864, view and detail (Source: Hatton 1964; Terry Williamson 1972).

not this is the case, this does seem to be a form of construction which any settler might invent for himself, as a matter of common sense, and it must in any case be a fairly modern one, given that it is more or less dependent upon nails.

\section{Pole and Rubble}

In Australia pole and pug construction could in theory have been influenced by Aboriginal practices, given that in South Australia, the Aborigines reportedly used saplings and mud for building (Elkin 1979, 50). But this can hardly have been pole and pug construction as later understood, for the Aborigines had no nails prior to European settlement. Split laths rather than round poles seem to have been use first used by the European settlers, consistent with English influence. However, the use of round poles and pug in Australia seems not to have been imported but rather was a local development arising from a similar form construction in mine workings where the packing was of stone, not of mud.

But there are other and quite different precedents for rubble-filled frames. Around Paris, it was reported:

The framed timber structure being completed, strong oak batten laths from 2 to 3 inches wide are nailed to the quarters horizontally, at 4, 6 or 8 inches apart, according to the character of the work, and the spaces between are loosely built up with rough stone rubble. A strong mortar is then laid on both sides at the same time, and pressed completely through from opposite sides, so that the mortar meets and entirely embeds the stone rubble by filling up all the hollows, and with so much body on the surface as to completely cover up and embed the timber and laths. (Allen 1854, 37)

Pierre Chabat's Dictionnaire illustrates something of the sort, except that the blocks of rubble are so large and square that they would have to be built into place before the laths were laid across the surface, rather than after. (Chabat 1875-1878, I, 952)

Pole and rubble construction appears in a number of Australian mining areas. In a house built in South Australia in 1851 by a German carpenter (who was generally following local rather than German practice), '1-inch-wide slats would be nailed onto the beams [sic] and the space between these and the outer wall would be filled with earth, small stones and even wood shavings.' (Listemann 1851) An example at Onkaparinga is of studwork solidly filled with rubble and finished in lath and plaster, and is also distinctive for being built of earthfast studs, with no ground plate (Young 1988, 184). Similar construction was used prior to 1880 at Moonta and Kadina: 'The favourite building materials of the miners were pines and battens, cut from the adjoining scrub, formed into a framework, and filled in with mud and stones, all of which were to be found close at hand.' (Franklyn 1881, 93) Surviving examples can be seen at sites in Victoria such as Duer's barn, Maldon of 1860 (Figure 18). Generally, it seems that pole and pug appears first in similar mining areas, such as the Central Goldfields of Victoria, and Hill End and Gulgong in New South Wales, and after that it spreads more widely. 


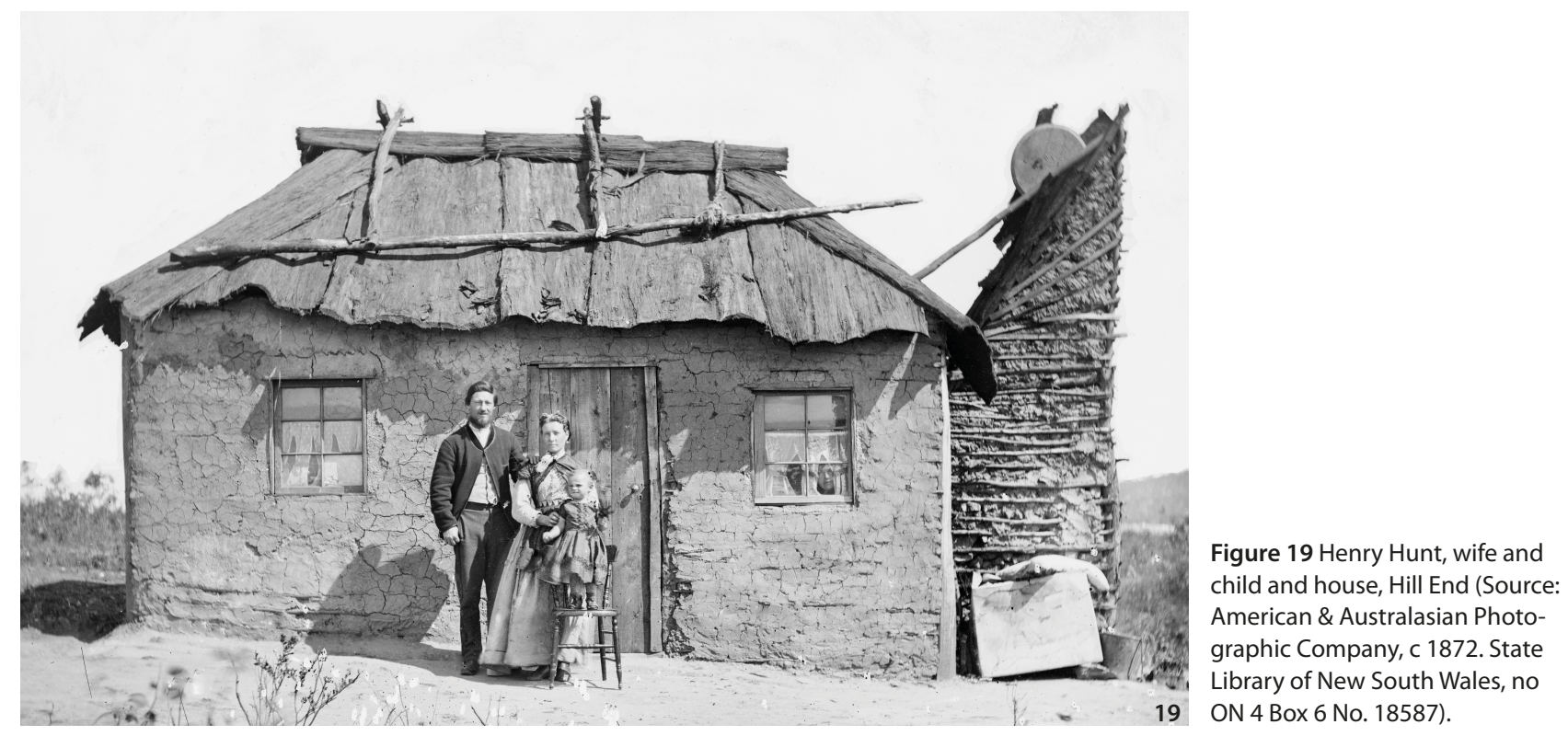

A writer in the Sydney Morning Herald in 1870 referred to a:

simple, style of 'cheap building' which has been resorted to with advantage in new colonies is the following: Make a frame of stout saplings driven into the ground, or (which is better) raised upon as rough stone foundation. Nail stout laths on either side of the saplings. Fill the spaces between the laths with rubble, gravel, or any hard substance which will lie close. To make the work solid throw in, as it goes on, a cement of moist clay or loam. If a little lime is mixed therewith it will be all the better. The wall thus made will be a very solid one, and may be finished off with plaster (Sydney Morning Herald, 8 April 1870, 5).

However, if the verticals were literally saplings the resultant wall would be too thin to be viable, and if it were raised on a stone foundation, rather than relying upon earthfast posts, there would be a major problem of bracing. The writer's next statement, that 'wattle and dab' is a rough edition' of this form of construction is also misleading, for if anything the reverse is the case.

It would be simplistic to suggest that the stone-packed technique is the sole origin of pole and pug construction, because there are other related traditions, and because some early examples in Australia have no connection with mining. One of these is the Caldwell house at Merricks on the Mornington Peninsula, Victoria, which is believed to date from 1860, though extended at later dates (Figure 19). Nevertheless, it can be said that pole and pug construction is strongest in mining areas, especially those where stone-packed frames are found, and there is probably a causal relationship.

The earliest description of the building of a pole and pug structure is that of the American A. B. Peirce in about 1872 or 1873 . He used split poles, and he may also have been the first to mis-describe this construction as wattle and daub. His three-roomed house at Hill End, New South Wales, was:

... constructed in the regulation style, without sills, by simply driving saplings into the ground at regular intervals, on either side of which were fastened the wattles or split limbs, forming horizontal half-rounds, the space between them being filled in solid with a mixture of earth, water, and grass. (Peirce and Leatherbee 1924, 128)

It so happens that Hill End and the neighbouring town of Gulgong are exceptionally well documented in photographs commissioned by B. O. Holtermann from Beaufoy Merlin in 1872 (Figure 20-22). They show pole and pug houses, often with bark roofs. In some the pole and pug construction is exposed; in some it has been roughly rendered over; and in some it has been smoothly plastered and ruled to look like ashlar stonework. The result is hardly vernacular at all.

Near Gulgong there still exists one building which has, as it were, translated this system of construction from the level of low technology to that of medium technology, though it still appears to be of $19^{\text {th }}$ century date. The framing is in sawn scantling rather than round timbers; on each face of the frame is nailed wire netting rather than saplings; the infill is still of mud, but the final rendering 

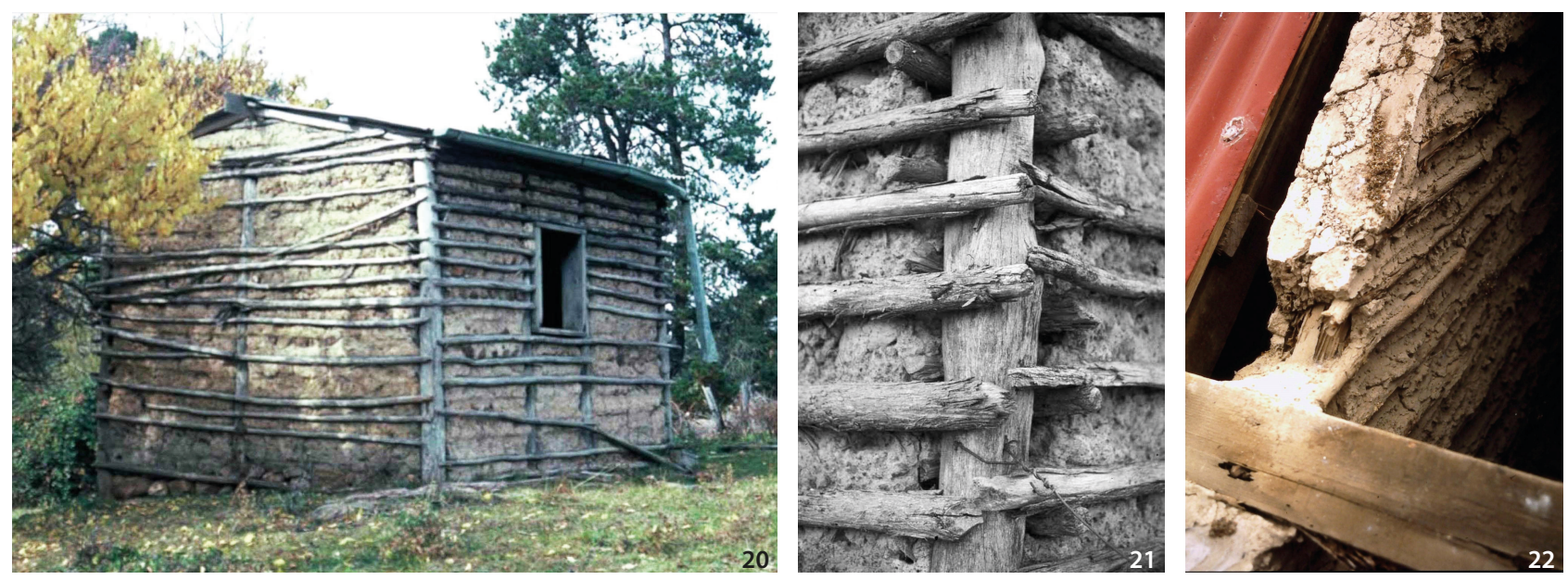

Figure 20 Hut at Wattle Flat, New South Wales (Source: Warwick Forge).

Figure 21 Hut at Wattle Flat, New South Wales, corner detail (Source: Miles Lewis).

Figure 22 Caldwell house, Merricks Road, Merricks, Victoria, 1860, detail at the edge of the gable (Source: Miles Lewis).

coat over the wall surface is of cement rather than the traditional mud and/or lime.

\section{Nails}

Pole and pug construction was dependent upon the availability of cheap nails. The mass production of nails had begun with the mechanisation of various parts of the nailmaking process from the 1790s onwards, especially in the United States precisely when wrought nails began to be produced entirely by machinery is unknown, but in 1834 Thomas John Fuller obtained a British patent for apparatus which produced both 'square-pointed' and 'flat pointed' [probably chisel pointed] nails, using hammers acting alternately to form the points, so as to retain the fibrous texture, and then finishing them with rollers ( $\mathrm{Me}$ chanics' Magazine 3 August 1839, 330).

By the 1850s Usonian factories were making what were described as wrought iron nails, on an improved system in which the fibre of the iron lay in the direction of the nail rather than transverse to it. For the smaller nails the machinery was 'self-acting' or automatic, but for the larger ones a boy had to supply the iron to the machine (Builder 5 July 1856, 374). The critical development was probably the wire nail, which had been long known in France but was not widely manufactured until the mid- $19^{\text {th }}$ century. By the 1870 s it was probably available in most parts of the world and at considerably less cost than traditional wrought nail. Hence it is from about this time that we should expect the appearance of pole and pug construction. And, indeed, that seems to be the case.

\section{Conclusions}

The conclusion of a taxonomic paper is the taxonomy itself, and it is hoped that the definitions and explanations given here will help to avoid ambiguities and misunderstandings in future (Figure 23).

There also emerges from this discussion a sort of hierarchy of sophistication. Materials such as grass, bamboo and timber have been used wherever they grow, as soon as tools have become available to cut them. Earth has been applied to them as a matter of course whenever climatic conditions demanded it. So when we find similar techniques in different parts of the world, we cannot infer that there has been any cultural connection.

A technique such as grid and daub is more sophisticated. While it must have been independently developed in many regions, it does have technical characteristics, such the spacing of the verticals and horizontals, and the manner in which they are tied together, which can indicate cultural connections. More work could be done on this question, especially in China and Japan.

Wattle and daub represents a stage further still. It was used in the Roman Empire, and it is possible that all examples in the Mediterranean and Europe are part of a common tradition. But in China (where it occurs but is not common) it may have developed quite independently.

Lehmwickel is more specific, and indeed is such a distinctive (and perhaps illogical) technique that it is hard to imagine it being invented or evolving independently in two different regions. And indeed it appears that all its manifestations, in different parts of the world, can be traced back to a common German origin. 

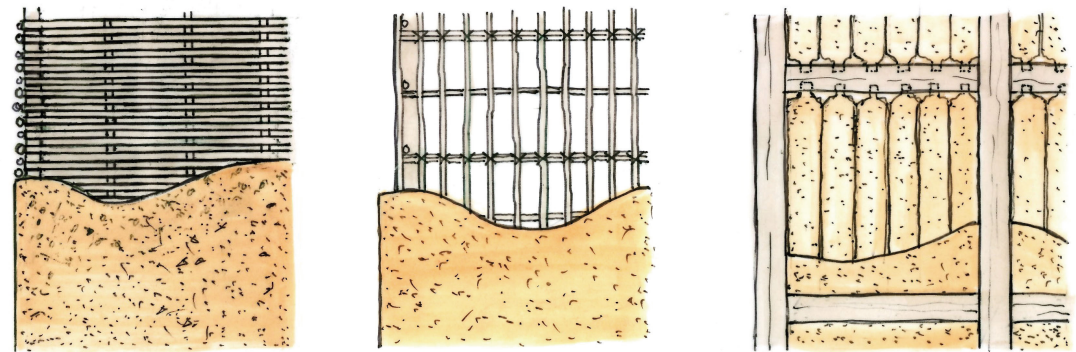

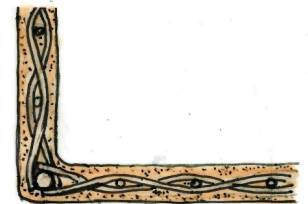

wattle and daub

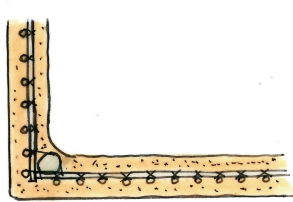

grid and daub

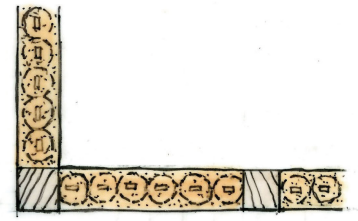

vertical lehmwickel
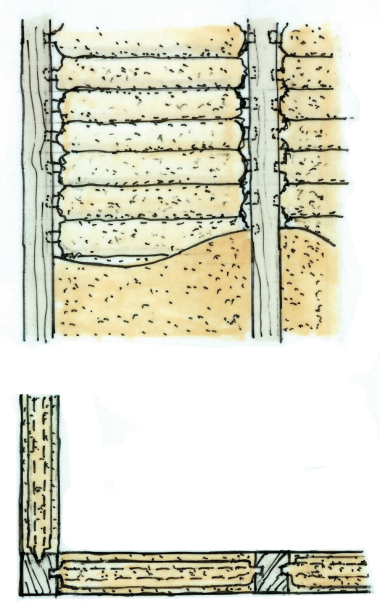

horizontal lehmwickel
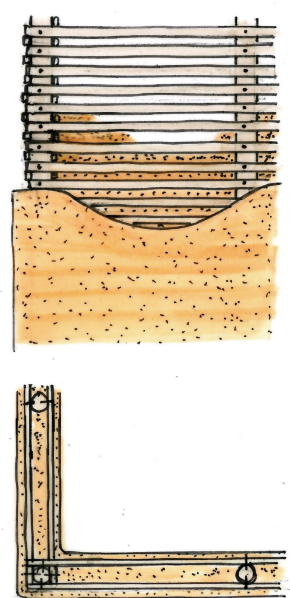

lath and pug
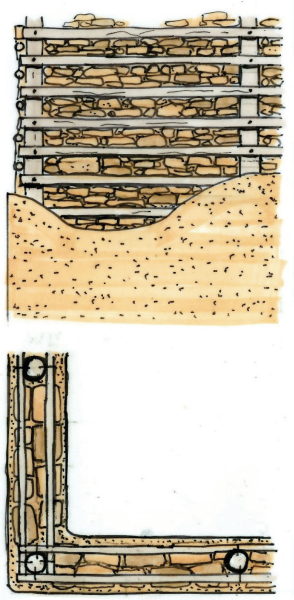

pole and rubble
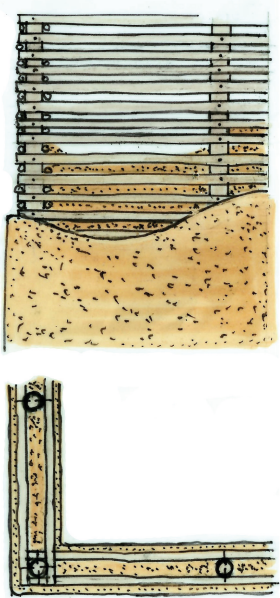

pole and pug

Figure $\mathbf{2 3}$ Composite vernacular construction types (Source: Terence Nott).

Finally, pole and pug can be seen as a common sense or inevitable form of construction, and it emerges independently in different places. But all examples of it depend upon the machine-made nail, and it appears only in the $19^{\text {th }}$ century. A technique which has had such a short history, and which depends upon an industrial product, challenges the very definition of vernacularity. That is not a question discussed in this paper, but it can be reported that scholars today generally accept that materials such as wire nails and galvanised corrugated iron can form a part of the vernacular.

\section{Note}

1. Original text in French is 'Pour faire les murs des côtés et $d u$ devant, en enfonce quelques morceaux de bois dans la terre à la distance d'un pied et demi environ, et les tenant aussi elévés que les poteaux qui soutiennent lédifice: pour les mieux fixer et les rendre plus solides, on en met deux ou trois en travers, Qu'on cloue aux poteaux: en entrelace ces bois avec des branches de saules ou de tout autre bois, et on applique extérieurement de la terre grasse battue avec de l'eau, pour en faire une espèce de mortier; au défaut du terre glaise on emploie la la terre commune, quion mêle avec un peu de chaux, pour qu'elle lie mieux.'

\section{References}

Allen, C. Bruce. 1854. Rudimentary Treatise on Cottage Building, 2nd ed. London: John Weale.

Arellano, J. F. 2006. "A Review of Historic Use of Earth in 
Construction in the Iberian Peninsula." CHS Newsletter 74 .

Artamonov, M. I. 1969. The Splendor of Scythian Art: Treasures from Scythian Tombs. New York: F A Praeger.

Arthur, Eric, and Dudley Witney. 1988. The Barn: A Vanishing Landmark in North America. New York: Arrowood Press.

Atkinson, William. 1805. Views of Picturesque Cottages with Plans. London: T Gardiner.

Bailey, Anne, and Robin Bailey. 2004. An Early Tasmanian Story: With the Oakdens, Cowies, Parramores, Tullochs and Hoggs. Toorak, Victoria: Blenallen Press.

Bedal, Albrecht, ed. 1999. Alter Bauenhäuser um Kocher und Jagst: zur Konstruktion und Funktion ländlicher Gebäude vor 1650 in Württemburgisch-Franken [Old Building Houses around Kocher and Jagst: On the Construction and Function of Rural Buildings before 1650 in Württemberg-Franconia]. Swäbisch Hall Verein Hohenlofer Freilandmusem.

Bradford, John. 1954. "Building in Wattle, Wood, and Turf." In From Early Times to Fall of Ancient Empires. Vol. 1 of A History of Technology, edited by Charles Singer, E. J. Holmyard, A. R. Hall and Trevor I. Williams. Oxford: Oxford University Press.

Bradley, Richard. 2005. Ritual and Domestic Life in Prehistoric Europe. London: Routledge.

Bulleid, A, and H. St. G. Gray. 1911. The Glastonbury Lake Village. Glastonbury: Glastonbury Antiquarian Society.

Chabat, Pierre. 1875-78. Dictionnaire des Termes Employés dans la Construction [Dictionary of Terms Used in Construction]. 2 vols, Paris: V A Morel.

Coles, J. M. 1983. "Archeology, Drainage and Politics in the Somerset Levels." Journal of the Royal Society of Arts, March 1983.

Cook, Olive. 1954. English Cottages and Farmhouses. London: Thames \& Hudson.

Crocker, A, and Son. 1804. “On Cottages.” In Communications to the Board of Agriculture on Subjects Relative to the Husbandry and Internal Improvement of the Country, Vol I, 2nd edition. London: Board of Agriculture.

Cunningham, Peter. 1827. Two Years in New South Wales. 2 vols. London: Henry Colburn.

Danachair, Caoimhín Ó. 1957. "Materials and Methods in Irish Traditional Building." Journal of the Royal Society of Antiquaries of Ireland 87: 61-74.

Edwards, Ron, and Wei-Hao Lin. 1984. Mud Brick and Earth Building the Chinese Way. 2nd ed. Kuranda: The Rams Skull Press.
Elkin, Adolphus Peter. 1979. The Australian Aborigines: How to Understand Them. Sydney: Angus \& Robertson.

Franklyn, Henry Mortimer. 1881. A Glance at Australia in 1880. Melbourne: Victorian Review Publishing.

Godley, Charlotte [John Godley, ed]. 1951. Letters from New Zealand by Charlotte Godley 1850-1853, Christchurch: Whitcombe \& Tombs.

Gouger, Robert. 1838. South Australia in 1837; in a Series of Letters: With a Postscript as to 1838. London: Harvey \& Darton.

Hatton, Warwick.1964. "Maldon.” 5 vols. BArch Thesis, University of Melbourne.

Innocent, Charles Frederick. 1916, The Development of English Building Construction. Cambridge: Cambridge University Press.

Kent, Nathaniel. 1775. Hints to Gentlemen of Landed Property. London: J Dodsley.

Ketteridge, Christopher, and Spike Mays. 1972. Five Miles from Bunkum. London: Eyre Methuen.

Lewis, Miles. 2017. “The Geography of Earth Building.” In Vernacular and Earthen Architecture: Conservation and Sustainability, edited by Camilla Mileto, et al., 9-14. Boca Raton: CRC Press.

Listemann, G. 1851. Meine Auswanderung nach Sued-Australien und Rueckkehr zum Vaterlande; ein Wort zur Warnung und Belehrung fuer alle Auswanderunglustige. Berlin. Translated and quoted by Lothar Brasse, 1988. “The German Contribution.” Historic Environment, VI, 2 \& 3: 48 .

Loudon, John Claudius. (1833) 1846. An Encyclopedia of Cottage, Farm, and Villa Architecture and Furniture. 2nd ed, London: Longman, Brown.

Lugar, Robert. 1807. The Country Gentleman's Architect. London: J Taylor.

Martin, Christopher. 1989. "Skeleton of Settlement: Ukrainian Folk Building in Western North Dakota." In Perspectives in Vernacular Architecture, III, edited by Thomas Carter and B. L. Herman 86-98. Columbia: University of Missouri Press: 86-98.

McCann, John. (1983) 2004. Clay and Cob Buildings. Princes Risborough: Shire Publications.

Meirion-Jones, G I. 1982. The Vernacular Architecture of Brittany. Edinburgh: John Donald.

Melero, N. 2016. "Performance and Current State of Latin American Rural Vernacular Architecture: A Challenge to be Addressed." In Vernacular Architecture Reflections: Challenges and Future, edited by Marwa Dabaieh and Valeria Prieto, 218-230. Lund: Media-Tryck. 
Morrison, Hugh. 1952. Early American Architecture from the First Colonial Settlements to the National Period. New York: Oxford University Press.

Murphy, David. 1989. "Building in Clay on the Central Plains." In Perspectives in Vernacular Architecture, III, edited by Thomas Carter and B. L. Herman, 74-85. Columbia: University of Missouri Press.

Nabokov, Peter, and Robert Easton. 1989. Native American Architecture. New York: Oxford University Press.

Owen, Blanton. 1989. “The Great Basin 'Mud' House: Preliminary Findings (abstract)." In Perspectives in Vernacular Architecture, III, edited by Thomas Carter and B. L. Herman, 245-246.

Papworth, Wyatt, ed. 1853-1892. The Dictionary of Architecture. 6 vols. London: Architectural Publication Society.

Peirce, Augustus Baker, and E. B. Leatherbee. 1924. Knocking About: Being Some Adventures of Augustus Baker Pierce in Australia. New Haven: Yale University Press.

Pliny the Elder [Caius Plinius Secundus], uncompleted 79. Naturalis Historia.

Prieto, Valeria, 1994. Vivienda Campesina en México [Peasant Housing in Mexico]. 2nd ed. Mexico City: Beatrice Trueblood.

Rivière, Georges-Henri. 1940s. "La Maison Rurale des Pays Normands." [Peasant Housing in Mexico.] In Chantier 1425 (reports of a survey of vernacular structures).

Rozier, F. P., ed. 1793-1800. Cours Complet d'Agriculture [Full Course of Agriculture]. 10 vols. Paris: Les Libraires Associés.

Smith, George Everard Kidder. 1981. The Architecture of the United States. 3. The Plains States and Far West. New York, Anchor Books.

Solis, Ruth, Jonathan Haas, and Winifred Creamer. 2001. "Dating Caral, a Preceramic Site in the Supe Valley on the Central Coast of Peru." Science 292: 723-726.

Ulrich, Roger Bradley. 2007. Roman Woodworking. New Haven: Yale University Press.

Van Beek, Gus, and Ora Van Beek. 2007. Glorious Mud. Washington: Smithsonian Institution.

Vicioso, Esteban Prieto. 2016. "Dominican Republic: Origins and Evolution." In Vernacular Architecture Reflections: Challenges and Future, edited by Marwa Dabaieh and Valeria Prieto, 88-109. Lund: Media-Tryck.

West, Trudy. 1971. The Timber-Frame House in England. Newton Abbot: David \& Charles.

Young, Gordon, ed. 1988. Onkaparinga Heritage. Adelaide: South Australian Centre for Settlement Studies. 